\title{
Frontiers in Law and Legal Scholarship
}

\author{
Richard Barnes and Ronán Long
}

\section{1 \\ Frontiers of Legal Scholarship}

This collection celebrates the contributions of Professor David Freestone to our understanding of international environmental law, particularly law of the sea and climate law. In doing so, it seeks to reflect his contributions by making its own mark on how we understand these fields of academic inquiry, as well as the realpolitik of international law-making on some of the most pressing and complex sustainability issues of our time.

As scholars we are unified by a drive not only to make sense of the world around us, but a desire to push the boundaries of that knowledge. To develop new ways of thinking. To apply existing understanding to novel situations. To advance new possibilities. In our own way, we are pioneers, forging new intellectual pathways into new frontiers. Each article or book published is a claim to new knowledge and understanding, a stake in the future content of our intellectual discipline. Each one marks out the territory of the unknown, it brings light to darkness, and serves to advance the rule of law as a catalyst for environmental, social, economic and in some instances political change. The present collection of essays explicitly situates itself at the frontiers of scholarship on law of the sea and climate change. Some scholarship does this explicitly. Some does this implicitly. However, scholarship infrequently reflects specifically on the idea of a frontier. How does the notion of a frontier define, challenge or influence what we do, and how do we in turn influence the idea of a frontier - or frontiers? This is the task of this collection - to explore the idea of frontiers in the law of the sea and climate change. In doing so, it also seeks to celebrate the specific contributions made by Professor David Freestone to our understanding of these important areas of study.

Research on the law of the sea has always been at the forefront of international law. The oceans have always been frontiers. They are spaces beyond the normal territorial bounds of States. They exist between States and so are fundamentally spaces where transactions and exchanges between States occur and are mediated. Ocean spaces present novel challenges. For example, the oceans are not a stable place in terms of their environmental, economic and social dimensions, and this fluidity challenges our approach to the 
imposition of fixed notions of space or location. ${ }^{1}$ The novelty of ocean spaces, the dynamic nature of the marine environment, and the vast unknown, mean that the oceans are a crucible of new ideas and innovations. As one of the most long-established areas of international law, law of the sea has experienced and adapted to many challenges and so can offer insights from experience into how to address challenges of international law-making more generally.

Frontiers are important, both practically and intellectually. The intergovernmental conference on marine biodiversity in areas beyond national jurisdiction speaks directly to the development of law and governance at or beyond the frontier. Intellectually, there appears to be growing interest in the concept of the frontier as a means of conceptualizing and explaining the function of international law, as well as the transitions that it is undergoing. ${ }^{2}$ Law is fundamentally about frontiers. Thus, law is taxonomic. ${ }^{3}$ Law classifies and organizes things according to their 'relationship'. Law also operates in terms of jurisdiction - the division of the world into planes of juridical authority between States, institutions and persons, as well as to reflect community interests between States and other actors. ${ }^{4}$ Although legal taxonomy may be a new project, or a new way of looking at the law, the concept of a frontier and the ways of thinking that it entails is an old one. The term frontier is often used to denote human exploration and fields of endeavour. Literature on the law of the sea echoes this but it has also been about the line between different spheres of State authority, as is evident from the contribution to this volume by Tulio Scovazzi. ${ }^{5}$ Echoes of it can be traced back the 'Grotian debates', when the

1 P Steinburg, The Social Construction of the Ocean (Cambridge University Press, 2001); H Jones, 'Lines in the Ocean: Thinking with the Sea about Territory and International Law' (2016) 4(2) London Review of International Law 307-343.

2 See, for example, the 'Exploring the Frontiers of international Law Project' at the Grotius Centre for International Law, https://www.universiteitleiden.nl/en/research/researchprojects/law/exploring-the-frontiers-of-international-law\#global-challenges,researchpossibilities Also, the $110^{\text {th }}$ ASIL Annual Meeting: Charting New Frontiers in International Law (2016), https://www.asil.org/resources/video/2016-annual-meeting.

3 E Sherwin, 'Legal Taxonomy' (2009) 15 Legal Theory 25-54.

4 E Benvenisti and G Nolte (eds), Community Interests Across International Law (Oxford University Press, 2018) passim.

5 T Scovazzi, 'The Frontier in the Historical Development of the Law of the Sea', Chapter 8, this volume. 
oceans were the means to and indeed object of imperial expansionism, exploration and endeavour. Under the banner 'freedom of the high seas', the oceans were a space between nations, something beyond the State (or at its periphery) and yet influenced by the State since the Treaty of Tordesillas. A space where interactions between States occur and the limits of State authority could be tested. As a space away from centres of authority, but between different centres of authority, the oceans were a space where new forms of action and interaction could emerge. The division and organization or order at sea were exercises in practical taxonomy. They continue to evolve today in debates about how to govern areas beyond national jurisdiction $(\mathrm{ABNJ})$, and in debates about what to include or exclude from the treaty and how to manage the overlaps between institutions and processes that already exist.

The story of the law of the sea is a story of frontiers. Just as nature abhors a vacuum, law demands completeness. ${ }^{6}$ So as human endeavour expanded across the oceans, law has filled the regulatory vacuum in relation to new spaces and enclosed the ocean in large part within national and international jurisdictions. Law of the sea is a story of the struggle to bring new spaces, situations and forms of social and economic reality within the rubric of new institutional structures underpinned by the rule of law. This is manifested in the division of the oceans into maritime zones, and the emergence of new regulatory regimes for ocean resources: fish, oil and gas, minerals, energy (thermal, current and wind), and genetic resources. As activity increased, so too did the need for secure, and sometimes exclusive, legal regimes. As claims to ocean space have grown, maritime boundaries have moved seaward from land territory: three or four nautical miles $(\mathrm{M}), 12 \mathrm{M}, 200 \mathrm{M}$ and beyond in relation to the continental margin. Throughout history, ocean frontiers have been moving spaces marking the gradual outward expansion of sovereign authority. ${ }^{7}$ As such, much of the evolution of the law of the sea has been framed in terms of how it addresses different frontiers - between different sectors, between different States, between States and community interests in the international commons, ${ }^{8}$ and between the different ideologies carried by these actors or

6 E Lauterpacht (ed.), Hersch Lauterpacht, International Law Collected Papers, vol 2 (Cambridge University Press, 1975) 221-222.

7 JA Knauss, 'Creeping Jurisdiction and Customary International Law' (1985) 15(2) Ocean Development \& International Law 209-216; B Kwiatkowska, 'Creeping Jurisdiction beyond 200 Miles in the Light of the 1982 Law of the Sea Convention and State Practice' (1991) 22(2) Ocean Development \& International Law 153-187.

8 S Ranganathan, 'Law of the Sea and Natural Resources' in Benvenisti and Nolte, above (n 4), 121-135. 
groups. The institutions of the State and of the international legal system have adapted to expanding oceans governance. And international laws have adapted to new situations. Even within existing maritime zones new types of frontier are emerging - generated by the increased use of spatial management through marine planning regimes and marine protected areas. These new forms of regulation are generating new frontiers. Despite being a point of potential conflict, the notion of the frontier has proved to be an integrative force, a crucible from which new legal regimes have emerged and continue to evolve in the progressive development of international law of the sea. States and individuals may disagree about where a boundary is drawn, but they agree on the need for boundaries.

This dynamic process continues with recent proposals for a new legal regime for areas beyond national jurisdiction. As law moves into new spaces (geographically, intellectually and conceptually) it is important that we understand the socializing processes whereby new law comes into being, how new ideas are generated, and how activities at the frontier and 'existing regimes' interact. Seldom is this process the simple transplanting of existing legal authority from one domain into another. Things are far more complex than this. Thus, what works for fishing in coastal waters does not necessarily work for fishing on the high seas because of different physical environments and jurisdictional requirements. Existing rules may require modification or augmentation if they are to apply to new activities or circumstances. This suggests that the frontier is a dynamic concept. But we need more than this if we are to make use of the concept as an interpretative prism through which to view and understand the purpose and scope of international law.

Adopting a taxonomic perspective, it is useful to define and organise what we mean by frontier. This gives us some intellectual purchase, but also helps with the practical organization of this collection. In its most basic terms, a frontier is a border between two States, or between something that is known and unknown. In much legal literature, the term is used lightly to mean a boundary, and it is not itself an analytical tool. ${ }^{9}$

Drawing upon the work of scholars researching the idea of the 'frontier', mainly in fields of legal geography, international boundaries and the protection of ocean and territorial space, one can adduce a number of deeper dimensions to the concept..$^{10}$ For de Sousa Santos, life at the frontier means

9 See, for example, Posner's work that explores points of connection between different fields of study: RA Posner, Frontiers of Legal Theory (Harvard University Press, 2004).

10 W Cronon, G Miles and J Gitlin (eds), Under an Open Sky: Rethinking America's Western past (ww Norton, 1992); B de Sousa Santos, 'Three Metaphors for a New Conception of Law: The Frontier, the Baroque and the South' (1995) 29 Law and Society Review 569-584; 
a selective use of social traditions by pioneers and the development of new forms of sociability. ${ }^{11}$ Law is a social construct and so brought into being by social actors. It is thus logical to consider actors at the heart of the process of frontier developments. The frontier space is a transitionary space where people pass through and where actions might have equally transitory effects. It is a space where there are more fluid social relations and engagement. This is because frontier actors exert more authority over local affairs than in metropolitan centres where social norms and legal rules hold greater sway. For example, on the high seas there is no exclusive spatial jurisdiction belonging to any single authority. Instead there is diffuse authority - connected to existing centres of authority through the sometime strong, sometimes weak notion of flag State jurisdiction over ships or nationality jurisdiction over individuals, as well as very limited reference to universal jurisdiction. This scenario points to a plurality of powers and juridical orders at the frontier, as well a mix of heritages and invention. This provides space for invention, a crucible of creativity, since these different traditions and actors must mediate their differences and deal with new situations. Yet the frontier is a vulnerable space: it is vulnerable to changes in the composition and mind-set of social and economic actors, especially at a local level. There is also institutional vulnerability since metropolitan institutions have less practical authority at distance from their power structures. There is environmental vulnerability because we simply know less about the environment and human impact upon it. There is less visibility of action, less knowledge, less consequence and control over actions, other than what those at the frontier bring with them. Established rules and conventions may simply not work without fear of sanctions. The frontier is vulnerable also because it a space subject to claim or capture by competing and sometimes conflicting forces. Existing legal institutions may not extend effectively to the frontier, weakening the rule of law, perhaps rendering frontier spaces and actors susceptible to harm. They are new spaces away from established power structures and institutions, so the force of the established is weaker, or at least is open to challenge.

Dynamic though frontiers are, it is possible to distil some common features of the frontier from the work of writers such as de Sousa Santos. The frontier can be characterized by a number of distinctive attributes including: it is populated by pioneer actors who shape subsequent developments; it is a peripheral space or subject matter; it has a transitory nature; there is scope for innovation

N Blomley, 'Law, Property, and the Geography of Violence: The Frontier, the Survey, and the Grid' (2003) 93 Annals of the Association of American Geographers 121-141. 
and opportunism; there is weak authority or a regulatory vacuum; and there is a plurality of mixture of values, heritages and cultures. Using these ideas as a template, this collection aims to explore how new international, transnational and global legal regimes emerge or operate at the frontier.

\section{3}

\section{Structure of the Collection}

The collection is divided into six parts, reflecting the analytical paradigm of the frontier concept. Building on the concepts developed in this chapter, Part 1 is concerned with the influence that different actors have on the way in which 'frontier space' is constructed and subjected to public order. Part 2 considers the frontier as transitional space; not merely a boundary, but a geographic space at the margins with a specific potential to mediate between the different established spatial orders or between established spatial orders and new spaces. In Part 3, we consider how the frontier influences established structures and institutions of law. As the frontier moves forward it leaves behind jurisdictional order (space), people and institutions that become part of the established public order, which in turn subsequently influences the progressive development of the law both with and beyond the frontier. Moving beyond the mere space, Part 4 explores the frontier as a creative space. By moving into a new space, existing rules and structures are left behind and opportunities exist for the creation of new social realities. Part 5 , the collection explores the relationship between frontiers and vulnerable regimes. Often frontiers involve extreme environments, or activities occur in conditions of uncertainty, so understanding the vulnerability of frontiers is critical to the development of new legal norms. In the final Part, the collection frames new frontiers in the context of new fields of endeavour where the foregoing considerations all come into play.

\subsection{Frontier Actors}

Part One of this collection is concerned with the influence that different actors have on the way in which 'frontier spaces' are constructed and subject to legal order. The frontier, understood as a developing legal space, can emerge when the spatial, temporal or material scope of international law expands into new areas. Often conduct in such areas precedes the capacity of States to regulate activities. Sometimes the emergent space/regulatory lacuna is exploited by actors in order to assert their interests free or in disregard of normal regulatory constraints or fail to reflect adequately community interests. Sometimes new 
or different actors come to the fore and play important roles in shaping how legal norms emerge or operate.

In the wider literature on frontiers, pioneers are actors engaged in developing the frontier space. Typically, they are individuals, but they include States, international organizations, companies and civil society organizations. Each actor brings different knowledge and experience to bear on frontier life and the construction of frontier order. Whilst international law is primarily conceived of as a formal system of rules between States, individuals must still mediate the interests of States. Diplomats negotiate, judge resolve disputes, and individuals catch fish, mine and sail. Historically, certain individuals stand out as pioneers of the law of the sea. François left his imprimatur on the Geneva Conventions of 1958, as the ILC Special Rapporteur. Pardo, 'father of the law of the sea conference' advanced the common heritage of mankind idea and did much to inject a sense of common interest within the law of the sea. Koh as President of the Third Conference on the Law of the Sea from 1980-1982, brought the negotiations on the United Nations Convention on the Law of the Sea (LOSC) to fruition. Writers such as Fulton, Jessup, Colombos, O'Connell, McDougal, and Burke have left indelible marks on the academic literature. As noted below David Freestone is making his mark, both on practice, through his leadership of the Sargasso Sea Commission, and in the intellectual and academic communities through his considerable writing, advocacy and activism on oceans and environmental issues.

Given the pivotal role of frontier actors, we asked our contributors to consider the following questions: Do actors conduct themselves differently in frontier spaces or on frontier issues? In what ways do different actors influence the development of law in frontier space and issues? What weighting do different actors bring to bear on frontier issues? Can different actors bring about different outcomes? Is greater control required over actors in frontier spaces to ensure peaceful co-existence of activities? The following chapters explore these issues, and perhaps unsurprisingly speak to the importance of holding actors to account.

In Chapter 2, David Dixon draws upon broader criminological and political science material to provide a scathing critique of Australian conduct in respect of East Timor. ${ }^{12}$ Following East Timor's declaration of independence, the tragedy and chaos that resulted from Indonesia's invasion and occupation of East Timor created a space and allowed and atmosphere where a political

12 Chapter 2: 'Water and Soil, Blood and Oil: Demarcating the Frontiers of Australia, Indonesia and Timor-Leste'. 
expediency and commercial opportunity thrived at the expense of legal principles, such as self-determination. A combination of access to oil resources, as well as fears over the spread of communism, political instability, and the priority of strategic relations with Indonesia led Australia towards dealing with Indonesia and negotiating boundary agreements despite questions over the occupation of East Timor. The influence of private concerns in this process is illustrated by the close relationship between the Australian government and Woodside Energy, Australia's largest independent oil and gas company, and the role the latter took in securing its favourable outcomes through joint development frameworks, and sought to influence later discussions over where oil processing should take place. Instability and uncertainty yielded opportunity. However, as Dixon then explains, once commercial opportunity had its foot in the door, then any profitable exploitation of resource opportunities required legal certainty. This can drive how States set their public policy: 'while borders and boundaries can be agreed by governments, operational decisions are made by corporations seeking the most commercially favourable option'. Dixon's chapter indicates that in frontier spaces the protection of peoples is more vulnerable due to the lack of order and the rule of law. Conditions of uncertainty or change appear to disinhibit States and render them susceptible to influence by private actors who pursue clear and strong economic interests. States may have a key role to play in setting the tone and direction of conduct in frontier spaces, but other actors influence this.

In Chapter 3, Charlotte Streck explores the developing role of non-State actors in the climate regime. ${ }^{13}$ She begins by explaining the recognition afforded to non-State actors within international agreements and institutions, before proceeding to map out and give a typology of actors and interests. In doing so, she is able to show the increased prominence of non-State actors in addressing climate change. The prominence of private actors is not merely a political choice, but a realization that different actors have different capacities, and these can and should be utilized. There is logic to this inclusive approach to governance: human induced climate change impacts everything - not just States. Accordingly, a wider range of actors has a role to play. This raises an interesting question as to whether we can really consider climate action a frontier. Certainly, it is an epistemological frontier, but in terms of governance, it is increasingly part of the mainstream. Climate is by no mean peripheral to us; climate change permeates all aspects of human existence. In recent decades,

13 Chapter 3: 'From Laggards to Leaders: The Evolving Role of the Private Actors in the International Climate Regime'. 
the range and type of non-State actors engaging in the process has increased. In particular, the private sector has identified the role of innovators, or potential crucibles for the development of local rules or model rules, and for influencing overarching public governance structures. For Streck, this model for action is one that requires suitable mechanisms for holding different actors to account. Thus 'a regime that puts emphasis on decentralized public and private action as the climate regime increasingly does - has to continuously assess progress and evaluate the effectiveness of the various strategies that contribute to the overall effectiveness of the regime. The regulatory framework supporting nonState action has to be evaluative, incorporating benchmarking and review and follow-up procedures beyond mere passive registration, to ensure full accountability of those that pledged action'.

There is an interesting contrast in tone between Dixon and Streck. Dixon shows the risks of partnership; Streck identifies potentially positive engagement in the process of international law-making. Dixon's case study is one where activities between States at the frontier are largely conducted through the medium of bilateral negotiation and diplomacy. For Streck, the forum is multilateral, with a broad inclusive approach to the constituency, thereby safeguarding the interests of the community as a whole. Both Dixon and Streck are sensitive to the potential limitations of different actors. This might simply be a question of good or bad motive. However, what appears to be a key issue is accountability, as facilitated through due process and transparency. Here, context matters. Higher degrees of public awareness, more inclusive fora, and clearly structured mechanisms for engagement provide stability and legitimacy. These can also strengthen accountability. The absence of a clearly identified role and structure for engagement seems to leave greater scope for untrammelled power. Frontier activities are often done at a distance, in complex or changing conditions. If a multiplicity of actors is involved in frontier activities, then some degree of transparency and mechanisms for accountability over these actors is critical if the rule of law is to thrive. As is evident from the discussion in chapters by Dixon and Streck, it would appear that these factors are more likely to exist within multilateral fora where there is greater exposure of underlying motives.

Accountability of actors in frontiers is a theme running through Chapter 4 by David Ong. Moving beyond an oceans' perspective, Ong focuses on the accountability of institutions for wrongs committed in the delivery of natural resource or infrastructure projects. ${ }^{14}$ International finance institutions

14 Chapter 4: 'Shared Responsibility or Institutional Accountability? Continuing Conceptual and Enforcement Issues for Grievance Mechanisms of Public and Private International Finance Institutions'. 
are increasingly involved in supporting major development projects in both developed and developing States. If the delivery of these projects contributes to violations of international social and environmental norms, then questions need to be asked about the role and accountability of international finance institutions for any such violations. In the literature, responses range from invocation of the 'shared responsibility' of both States and international/ transnational institutions involved in a project, to institutional accountability mechanisms for responding to the claims of victims. Given Freestone's work within and examining the role of the international finance institutions, ${ }^{15}$ it is appropriate to revisit how we conceptualise and understand the responsibility/accountability of non-State actors for these violations. Ong considers the effectiveness of these grievance mechanisms in two case studies, which highlight the continuing enforcement deficiencies of traditional mechanisms for addressing violations of international law and the difficulties encountered as a matter of practice in engendering greater compliance with universally agreed social and environmental standards of behaviour. This leads him to conclude that neither conceptual innovations such as 'shared responsibility', nor institutional grievance mechanisms, are ultimately able to surmount the continuing lack of effective enforcement within international law and international organizations.

\section{2 $\quad$ Frontiers as Transitional Spaces}

There is a distinction between a boundary and a frontier. A boundary is a linear concept, marking the precise division between two spaces. Thus, something lies one side of the line or the other. An activity falls to be governed by one regime or another: high seas or exclusive economic zone (EEZ); territorial sovereignty or maritime jurisdiction. A frontier can be a line, but it is more than this. Frontier can also be a space - the 'outer space' or the high seas. A frontier can be a dynamic zonal or spatial concept; a space between the unregulated or

15 D Freestone, 'The World Bank's Prototype Carbon Fund: Mobilising New Resources for Sustainable Development' in S Schemmer-Schulte and K-Y Tung (eds), Liber Amicorum for Ibrahim S.I. Shihata (Kluwer Law International, 2001); D Freestone and C Streck, The Kyoto Protocol: Current Legal Status of Carbon Finance and the Flexible Mechanisms, Special Issue (2007) 15 Environmental Liability 47-124; D Freestone, 'The Establishment, Role and Evolution of the Global Environment Facility: Operationalising Common but Differentiated Responsibility?' in TM Ndiaye and R Wolfrum (eds), Liber Amicorum for Thomas A. Mensah: Law of the Sea, Protection of the Marine Environment and Settlement of Disputes (Martinus Nijhoff, 2007) 1077-1107. 
unknown and the regulated or settled space of human activity. ${ }^{16}$ It can also be a space at the limits of understanding or achievement. In such case, it would appear that frontiers have tended to provide a transitional function in the absence of precise boundaries or agreement about how spaces can or should be regulated. ${ }^{17}$

It would appear that law of the sea has traditionally favoured the delimitation of precise boundaries; lines which establish precisely the extent and limit of States' rights and duties. In doing so, it has sought to reconcile the spatial jurisdiction of States and to safeguard community interests in matters of common concern including navigation rights and freedoms. ${ }^{18}$ This approach favours order and simplicity. However, sometimes boundaries cannot readily be fixed, due to sovereignty disputes, ${ }^{19}$ the oscillation of the applicable delimitation methods, ${ }^{20}$ and changing geographical circumstances due to dynamic and ambulatory coastlines. ${ }^{21}$ These concerns are present all too visibly in the South China Sea and other disputed sea areas. ${ }^{22}$ In many disputed areas, there is increasing interest in the use of provisional agreements to manage activities. ${ }^{23}$ In part, this is done or offset more serious disputes, but it is also driven by pragmatic interests in facilitating resource exploitation, ${ }^{24}$ and this can

16 MB Rasmussen, and C Lund, 'Reconfiguring Frontier Spaces: The Territorialization of Resource Control' (2018) 101 World Development 388-399.

17 P Hoare, The Sea Inside (4th Estate, 2014) 17.

18 Y Tanaka International Law of the Sea (3rd ed, Cambridge University Press, 2019) 4-5.

19 See generally, JM van Dyke (ed.), Maritime Boundary Disputes, Settlement Process, and the Law of the Sea (Martinus Nijhoff, 2009).

20 See M Evans, 'Maritime Boundary Delimitation' in DR Rothwell, AG Oude Elferink, KN Scott and T Stephens (eds), The Oxford Handbook of the Law of the Sea (Oxford University Press, 2015) 254-279, 278.

21 J Lisztwan, 'Stability of Maritime Boundary Agreements' (2012) 37 Yale Journal of International Law $153^{-200}$. This is an area that Freestone has been particularly involved in recent years. See D Vidas, D Freestone and J McAdam (eds), International Law and Sea Level Rise. Report of the International Law Association Committee on International Law and Sea Level Rise (Brill, 2019).

22 C Yiallourides, Maritime Disputes and International Law. Disputed Waters and Seabed Resources in Asia and Europe (Routledge, 2019).

23 R Lagoni, 'Interim Measures Pending Maritime Delimitation Agreements' (1984) 78 American Journal of International Law 357; D Anderson and Y van Logchem, 'Rights and Obligations in Areas of Overlapping maritime Claims' in S Jayakumar, T Koh and R Beckman (eds), The South China Sea Disputes and the Law of the Sea (Edward Elgar, 2014) 192-228; British Institute of International and Comparative Law (BIICL), Report on the Obligations of States Under Articles 74(3) and 83(3) of UNCLOS in Respect of Undelimited Maritime Areas (BIICL, 2016).

See also, Dixon, Chapter 2, this volume. 
drive the shape of 'interim' legal regimes. Although these arrangements are intended to be provisional, pending the final delimitation of boundaries, they may endure for long periods of time and influence eventual delimitation settlements or activities post boundary delimitation. These interim arrangements are a form of frontier, transitional zones that feature special rules shaped by the competing values and interests that influence the conduct of activities in the disputed maritime area. They are frequently characterized by a balancing of interests and a suspension of activities that would jeopardize or hamper enduring settlements.

The transitional nature of such spaces raises a number of questions about the operation of international law: Are different rules/institutions required to govern frontier spaces/issues? Do rights and duties that emerge in frontier spaces have a lasting impact on the development of international law? Are existing rules/institutions well-suited to frontier spaces? The chapters in Part Three explore how legal rules have developed to accommodate activities in frontier spaces.

Maritime delimitation is fundamentally concerned with boundaries or frontiers. As Robin Churchill observes in Chapter 5 , there are around 180 areas where no boundary exists. ${ }^{25}$ This means that frontiers are an important aspect practical consideration in the law of the sea. International law recognizes the challenges of regulating such spaces and establishes a series of obligations for States that seek to avoid lawlessness and the sub-optimum utilization of resources. As noted above, the meaning and effectiveness of such obligations has garnered recent interest. Building on this literature, Churchill focuses on how the quality of such obligations varies according to the type of frontiers concerned including overlapping E EZ/continental shelves, continental shelves beyond $200 \mathrm{M}$, and overlapping territorial seas. The reasons for this are perhaps historical, noting that the use of a median line for the territorial sea was more settled in law following agreement on the 1958 Territorial Sea Convention. ${ }^{26}$ In contrast, the controversial issues of EEZ and continental shelf boundaries generated rules operating at a higher level of generality. Accordingly, the latter focused more on process (resolving conflicts) than substance (i.e., how to delimit). This suggests that for maritime frontiers there is a much greater focus on mediating potential conflict than governing substantive activities. If rules can mediate conflict first, then States can perhaps better pursue the development of substantive rules inter se within a relatively well-defined space.

\footnotetext{
25 Chapter 5: 'International Law Obligations of States in Undelimited Maritime Frontier Areas'.

$26 \quad 516$ UNTS 205.
} 
It is difficult if not impossible to explain what motivates States to settle their boundaries in particular ways. In concluding his chapter, Churchill observes that one can only assume 'that the primary motivation is self-interest rather than acting in response to obligations in the LOSC.27 Arguably, this much perhaps is implicit in the function of law, and the focus on obligations of restraint. Restraint implies a check on the exercise of pure self-interest. However, the link between any State practice and the meaning of such an obligation is not at all clear. It appears impossible to discern precisely the influence of specific rules of the law of the sea beyond urging restraint. Geographical or geological facts may have a role to play in the generation of zones, but it is also equally difficult to determine their influence on how activities in frontier spaces are conducted.

Arguably, geographical or physical factors are concerns that are more acute when it comes to baselines, probably because baselines are fundamental to the determination of the spatial limits of all maritime zones, and not merely specific maritime areas. Chapter 6 by Clive Schofield on ambulatory baselines highlights the importance of a core function of the law of the sea, which is to determine the precise spatial extent of coastal State jurisdiction over maritime space. ${ }^{28}$ The law of the sea operates according to certain factual conditions related to geographical features (i.e., general position of low water-line as well as the existence of specific features like low-tide elevations, bays and inlets). ${ }^{29}$ However, these conditions are not fixed; some of them are dynamic, and so the law of the sea must respond to any changes in the physical condition of a coastline. In recent years, we have become attuned to the fact that coastlines are vulnerable to the effects of climate change, through erosion or sea level rise. Schofield examines how changes to the location or indeed existence of baselines impacts upon entitlements to maritime zones. His analysis is revealing, and several points should be highlighted. First, the vulnerability of coastlines is shown to present to some States an existential threat, thus the frontier is not merely about where a line is drawn on the sand, it is about the potential existence of the State. This raises the stakes that States, individually and collectively, have in the game. Law of the seas assumes the land dominates the sea. ${ }^{30}$ But how can the land dominate the sea, when there is no land? Second,

27 Churchill, Chapter 5, this volume, 170.

28 Chapter 6: 'A New Frontier in the Law of the Sea? Responding to the Implications of Sea Level Rise for Baselines, Limits and Boundaries'.

29 See 1982 United Nations Convention on the Law of the Sea (LOSC), 1833 UNTS 3, Section 2.

$30 \quad$ North Sea Continental Shelf Cases (Federal Republic of Germany v Denmark; Federal Republic of Germany v The Netherlands), Judgment, (1969) ICJ Reports, p 3, para 96. 
Schofield's focus on the dynamic nature of the coastal line shows that frontiers are not merely issues concerned with the limits of ocean space distant from our shores, they are closer to home, fundamentally connected to coastlines. How we define our baselines determines how and where more distant maritime frontiers exist. Third, the LOSC was drafted at a time that coincided with broad stability in global sea levels. However, the coastline is far from stable and we need to adapt our legal rules to reflect this. The novelty of the challenge provides scope for wider discussion about the way the law of the sea should progressively develop. Paradoxically, the law is sometimes more immutable than physical fact. As Freestone has argued, ${ }^{31}$ maritime boundary agreements are not subject to change resulting from ambulatory baselines, protected as they are by the principle rebus sic stantibus. ${ }^{32}$ This presents an interesting contrast with situations of maritime boundaries that are unilaterally determined in accordance with Losc. Such boundaries would be vulnerable to change because there is currently no rule that preserves existing maritime entitlements. This clearly produces iniquitous results because the mitigation of the adverse effects of sea level rise is decoupled from the root cause of the problem and linked to the legal method used to frame a maritime entitlement. There thus remain difficult issues to be resolved in relation to baselines that are fundamental to stability and clarity in the international legal order.

In Chapter 7, Seokwoo Lee and Lowell Bautista investigate further the existential threat posed to statehood by sea level rise. ${ }^{33}$ This is an epistemic matter, since international law does not directly address the question of the extinction of the physical State due to climate change: 'An inquiry into the legal rules in respect of the extinction of States contextualizes and recognizes the phenomenon of a rapidly changing physical world impacted by climatic changes whose consequences are not easily accommodated by existing theories of international law' ${ }^{34}$ It is also a question of great practical importance for some of the least developed countries in the world including small island developing States most especially. This is because low-lying territories are likely to become uninhabitable far before the State disappears 'below water'. There will be a transition to 'statelessness'. Along the way, this will manifest itself in loss of

31 D Freestone, 'International Law and Sea Level Rise' in RR Churchill and D Freestone (eds), International Law and Global Climate Change (Graham and Trotman/Martinus Nijhoff, 1991) 109-125, 114.

32 Schofield, Chapter 6, this volume, 180. This rule is embodied in Article 62(1) of the Vienna Convention on the Law of Treaties, 1155 UNTS 331.

33 Chapter 7: 'Climate Change and Sea Level Rise: Nature of the State and of State Extinction'.

34 Ibid 213 . 
population as people move from threatened areas, potentially across borders to other States. It may then escalate to governmental challenges as the capacity to govern is jeopardized. Lee and Bautista are keen to remind us that the issue is not so much the loss of territory, but the consequences this has for people, and questions of statehood should not obscure more fundamental moral and legal commitments to displaced and potentially displaced peoples. Questions of maritime space, statehood and individual well-being cannot be considered apart. In short, the landward push of maritime frontiers has profound implications for the identity and function of States.

\subsection{Frontiers and Established Regimes}

So far, the main concern of the authors has been how law adapts to the new situation of the frontier. However, as Lee and Bautista alluded to in their discussion of the impact of changing maritime frontiers on statehood, law and practice at the frontier can influence how law works at the centre, that is to say within existing institutions. As the frontier moves it changes the way existing legal institutions, concepts and assumptions operate because 'more' is brought within the scope of existing legal regimes or existing areas of social concern, and so existing institutions and practices must evolve and accommodate the new. This may be in terms of 'mere' regulatory workload, where the increase in regulatory load alters existing priorities and practices, or it may be in terms of adapting to new factual situations. Either way, the 'centre' is repositioned (e.g., reframed or displaced) within the changed geographic, political or legal space, as States are forced to accommodate the interests of other States within their legal domain. A good example is the expansion of coastal State jurisdiction. For centuries, this process has been at work as coastal State jurisdiction has gradually expanded to encompass significant areas of ocean space, which in turn has resulted in a change in the rights and responsibilities of coastal States over natural resource management. This process is dynamic and as new frontiers emerge new activities may become possible. For example, with receding icecaps in higher latitudes due to the adverse effects of human induced climate change, this in turn allows for new navigation routes or fishing activities. These activities must be accommodated within existing regimes. This on the one hand may generate conflict between different interests, such as navigation rights versus the protection of the environment, or require on the other hand the allocation of new benefits or burdens for States and other actors. This may generate conflict because existing approaches are ill-suited to the new reality. If disputes are to be avoided, then existing regimes must evolve and adapt to new and changing circumstances. 
The following chapters explore the following questions: which behaviours and practices has law of the sea influenced, and how? How is conflict managed as circumstances change and evolve, especially between established and new activities? Are there any issues that remain problematic as frontier emerge and become part of the established legal order and come within the remit of existing institutions?

Tullio Scovazzi revisits, in Chapter 8, the venerable subject of expanding coastal State jurisdiction to assess the factors at play that have driven the evolution of different maritime zones. ${ }^{35} \mathrm{He}$ argues that whilst the law of the sea has as its foundation the principle of the freedom of the sea, this principle was elaborated at a time when no-one could conceive of the technological advances that would come in the future, such as super tankers or the exploitation of the marine genetic resources of the deep seabed. This led to the rebalancing of conflicting principles and the progressive development of new norms with a view to balancing freedoms with other interests - particularly those of a collective character, such as the protection of the marine environment. The expansion of coastal State jurisdiction has generated considerable change in how States govern maritime activities, increasing considerably their responsibilities over coastal waters. Looking to the future he observes that the changing institutions are not merely those of the coastal State, but that the common heritage principle will also have to evolve in a progressive fashion if it is to conform to the needs of new ocean use realities. In this context, it is also evident that the community interests of mankind as a whole will require the continued development of new frontiers in the law of the sea that go beyond its traditional characteristic as an inter-State system of regulation.

Navigation is one of the oldest uses of the oceans; it is protected strongly through regimes of freedom of navigation, transit and innocent passage. Shrinking icecaps have opened up new navigation routes through some of the world's most vulnerable sea areas in the Arctic. Whilst the law of the sea establishes a more or less comprehensive framework for navigation, as Scott Davidson shows in Chapter 9, this regime has been tested by the prospects of navigation through the Northwest Passage. ${ }^{36}$ The physical environment within which navigation occurs is a complicating factor and requires the development of new and precautionary measures, as shown by the development of

\footnotetext{
35 Chapter 8: 'The Frontier in the Historical Development of the International Law of the Sea'.

36 Chapter 9: 'New Ways to Break the Ice: Emerging Approaches to the Regulation of Navigation in the Northwest Passage'.
} 
the Polar Code. ${ }^{37}$ This places additional burdens on States to exercise vigilance and control through port State inspections and or the designation of navigational routes. He concludes, as the "ice frontiers" move or disappear, they are replaced with others as the challenges relating to the safe use of the passage.'.38 Beyond this, it represents an immediate increase in regulatory responsibilities that must be absorbed within existing regimes. It also signifies a growth in responsibilities to cooperate. At yet another level, it shifts, even if slightly, the balance between freedom of navigation and protection of the marine environment, further recognizing the importance of the latter in the equation.

Just as navigational opportunities are opening up in Arctic waters, so too are new potential fishing grounds. As Rosemary Rayfuse points out in Chapter 10, the 'Arctic represents one of the last great regulatory frontiers on earth, this expanding opportunism has not been occurring in a complete legal vacuum. ${ }^{39}$ Whilst the Agreement to Prevent Unregulated High Seas Fisheries in the Central Arctic Ocean may be new, it has a legal pedigree. ${ }^{40}$ And perhaps more importantly, it is 'truly precautionary', establishing a an agreement for fisheries in advance of fisheries taking place. This changes how we might view fisheries management, confirming that new or exploratory fisheries must have a sustainable basis. Admittedly, it falls short of a complete moratorium on fishing which some had hoped would be adopted, but it puts in place mechanisms that will hopefully ensure no commercial fishing takes place without scientific evidence of its sustainability. At the very least this is further evidence of the continued rise of the precautionary approach to international fisheries management. ${ }^{41}$

In Chapter 11, Nilüfer Oral explores a third frontier - plastic pollution and the extent to which existing rules on the protection of the marine environment can prevent or mitigate this problem. ${ }^{42}$ Plastics pollution presents challenges

37 International Code for Ships Operating in Polar Waters, Imo Doc ME PC 68/21/Add.1 (5 June 2015), Annex 10, 3 .

38 Davidson, Chapter 9, this volume, 262.

39 Chapter 10: 'Taming the Wild North? High Seas Fisheries in the Warming Arctic'.

40 See R Caddell, 'Precautionary Management and the Development of Future Fishing Opportunities: The International Regulation of New and Exploratory Fisheries' (2018) 33 International Journal of Marine and Coastal Law 199-26o.

41 D Freestone, 'International Fisheries Law since Rio: The Continued Rise of the Precautionary Principle' in AE Boyle and D Freestone (eds), International Law and Sustainable Development. Past Achievements and Future Challenges (Oxford University Press, 1999) $135^{-164 .}$

42 Chapter 11: 'From the Plastics Revolution to the Marine Plastics Crisis: A Patchwork of International Law'. 
for the law of the sea since most plastics are the result of land-based sources of pollution. ${ }^{43}$ The LOSC remains the only binding global instrument that establishes obligations on States to prevent such pollution, but it remains general, strengthened by obligations of due diligence. In practice, clearer technical rules and standards are required to govern the creation, use, recycling and disposal of plastics. The present fragmented system of rules covering different aspects of plastic pollution (ghost fishing gear, dumping, transport and riparian pollution) means that there are gaps, both geographically, and in terms of material scope. As Oral argues, this may require new instruments and adaptation of existing regime. Whatever approach is taken, a holistic view of the problem is required.

Echoing concerns about how international law can disconnect related issues, in Chapter 12 Dan Bodansky observes that 'Despite these physical interconnections [between ocean and climate], neither the ocean regime nor the climate change regime has historically had much to say about the other. ${ }^{44}$ However, rather than push for integration, Bodansky argues that the current 'division of labour' makes sense. ${ }^{45}$ This is because mitigating climate change is something the law of the sea, unlike climate law, has limited capacity to address. On the other hand, adapting to climate change is something that law of the sea can address, for example, through adjusting how fisheries are managed in light of climate induced changes to species distribution or the impacts of sealevel rise. In short, many of the provisions of the Law of the Sea Convention are simply not well-suited to addressing climate change and we should not force them to a task for which they were not designed. For the longer term, climate law should leave the door open for ocean-based mitigation measures, as and when they become a technical and political option. Until then, Bodansky argues forcefully for a more nuanced appreciation of the strengths and weakness of climate and oceans laws before mobilizing them to action in responses to climate change. Sometimes it is useful for legal regimes and institutions to maintain their differences. Again, the concept of frontiers provides an innovative framework in understanding the dynamics that are at play in such processes and reconciliations.

43 M Haward, 'Plastic Pollution of the World's Seas and Oceans as a Contemporary Challenge in Oceans Governance' (2018) 9 Nature Communications 667, 667.

44 Chapter 12: 'Oceans and Climate Change Law: Exploring the Relationships'.

45 Ibid $318-9$ and 322. 


\subsection{Frontiers and Vulnerable Regimes}

As noted in Section 2 above, frontiers are vulnerable spaces. This is may be physical vulnerability or legal vulnerability. The oceans are a vulnerable physical frontier. Our oceans are increasingly understood as comprised of vulnerable ecosystems. ${ }^{46}$ These vulnerable ecosystems may find it difficult to resist external forces - both natural and man-made. Many activities at the frontier are nascent or poorly understood, such as the impacts of fishing on vulnerable marine ecosystems or indeed cumulative impacts of anthropogenic activities on the conservation status of deep ocean biodiversity. ${ }^{47}$ Despite much scientific progress, much of our oceans remain poorly understood. It is frequently remarked that we know more about the topography of the moon than we do about the floor of the ocean, and this gap in knowledge can render the oceans even more vulnerable. Novel ventures are untested and therefore uncertainty exists as to how such ventures could or should be conducted. At the same time, the oceans can be a hostile environment and far from centres of authority and support. Activities are conducted far from regulatory oversight and practical support systems and this may generate acute regulatory challenges and practical difficulties in establishing and implementing effective enforcement and compliance systems. This legal vulnerability is exacerbated by the transitory nature of frontier spaces.

A number of important questions arise about how vulnerable regimes are regulated: What approaches work best to protecting vulnerable spaces or resources, and why? Can lessons/practices from areas within national jurisdiction be applied successfully to ABNJ? What innovative practices are working, and why? The chapters in this part, and Part 5, explore different 'ocean frontiers', and assess how legal regimes have developed to accommodate the particular vulnerabilities of regulating ocean space and activities distant from centres of authority.

In Chapter 13, Amrisha Pandey and Surya Subedi argue that traditional legal frontiers must be challenged in light of growing concerns about the protection of the marine environment. ${ }^{48}$ Again the tensions between individual State

46 See United Nations General Assembly, Resolution 74/19: Oceans and the law of the sea, adopted 1o December 2019, esp para 285 .

47 L Kimball, 'Deep-Sea Fisheries of the High Seas: The Management Impasse' (2004) 19 International Journal of Marine and Coastal Law 259-287; R Caddell, 'International Environmental Governance and the Final Frontier: The Protection of Vulnerable Marine Ecosystems in Deep-Sea Areas beyond National Jurisdiction' (2018) 29 Yearbook of International Environmental Law $1-36$.

48 Chapter 13: 'Enhancing State Responsibility from Environmental Implications of the South China Sea'. 
interests and community interests are at play. Law of the sea has its origins in the former, and yet in many instances seeks to advance the latter, particularly so in the context of the duty imposed on States in protecting and preserving the marine environment. Indeed, Rüdiger Wolfrum expressed the view in his separate opinion in the Mox Plant case that 'the duty to cooperate denotes an important shift in the general orientation of the international legal order. It balances the principle of sovereignty of States and thus ensures that community interests are taken into account vis-à-vis individualistic State interests.' ${ }^{49}$ However, there is no strict demarcation of individual/community interests, but rather a dynamic legal framework that evolves according to contemporary interests and new understandings of human/ocean interactions. Using the South China Sea case as a case study, Pandey and Subedi test whether extant and evolving provisions of international law can be used to hold States to account for harm not just to individual interests, but to those of the wider community of States. Unfortunately, they find this framework lacking. This situation demands progress towards and investment in modes of secondary responsibility and to make use of this to protect the global commons from the harmful impacts of human activities or intervention. The argument is ambitious, but it recognizes that in the absence of individual action, community action may be required to ensure critical harm is not caused to vulnerable marine environments.

Arguably, the precautionary principle is the most appropriate way of handling the challenges of uncertainty within vulnerable marine ecosystems. 'Where there are threats of serious or irreversible damage, lack of full scientific certainty shall not be used as a reason for postponing cost-effective measures to prevent environmental degradation.' ${ }^{50}$ However, in light of continued decline in the state of the oceans, it is right to ask whether the precautionary principle has lived up to expectations. In Chapter 14, Warwick Gullett addresses this question..$^{51}$ Having traced the principle's development, he notes that its success has been in facilitating explicit consideration of uncertainty in marine environmental decision-making. The battle for relevance has been won, and the principle has permeated into most if not all areas of marine management: licensing, the development of marine protected areas (MPAs), ship

49 Separate Opinion, MOX Plant (Ireland v United Kingdom), Order of 13 November 20o1, ITLOS Reports 2001, 89.

$5^{\circ}$ Rio Declaration on Environment and Development, UN Doc A/CoNf.151/26 (Vol 1) (12 August 1992), Annex 1, Principle 15.

51 Chapter 14: 'The Contribution of the Precautionary Principle to Marine Environmental Protection: From Making Waves to Smooth Sailing?? 
routing requirements, and the conduct of impact assessments. Despite this, efforts are still required to flesh out the meaning of the principle, and to improve the application of the principle in practice. The battle for effective implementation remains. In 1992, Freestone cautioned that ineffective implementation of precautionary environmental regimes 'may be worse than worthless if they give the impression that all is well when the opposite is in fact true. ${ }^{2}$ Close to three decades later, Gullett echoes this same sentiment. Although regimes may remain vulnerable, the challenges associated with their implementation remain all too persistent.

\section{5 $\quad$ Frontiers as Creative Spaces}

If existing approaches do not work, then solutions must be found. In frontier spaces, there is arguably greater scope for the creative or selective use of legal norms and traditions. Legal regimes are less well-developed because there has simply been less opportunity and time for rules to emerge in a new space. Or, their application is more highly dependent upon agreement between the frontier actors. This is not to say that the creation of new rules is easy. Far from it. The same reasons why there is 'less' law can also limit the opportunities for law creation going forward. What then is more useful to consider is what differences a frontier space can make to the way in which new rules emerge, and to the form that they may take. Is there evidence that different approaches and mixes of rules operate in frontier spaces or on frontier issues? Does the development of legal rules and principles accommodate different disciplinary approaches in a frontier space? What innovations have or could emerge in frontier contexts?

With the benefit of hindsight, there is little doubt but that the progressive development of law of the sea since the $19^{\text {th }}$ century is closely interwoven with the results of marine scientific research and deep ocean exploration. There are many cogent examples of how science has acted as a catalyst and shaped new normative frontiers in international law. This close symbiosis between marine and climate science and their influence on multilateral and regional regulatory developments has in turn proved to be a fertile ground for much of Freestone's insightful scholarship on many contemporary and contentious topics. Among others, this includes the advisory jurisprudence of the Seabed Disputes Chamber of the International Tribunal for the Law of the Sea with

52 D Freestone, 'The Challenge of Implementation: Some Concluding Notes' in A Boyle and
D Freestone (eds), International Law and Sustainable Development (Oxford, 1999) 359, 360. 
respect to activities in the Area; ${ }^{53}$ a guide to the implementation of the 1993 FAO Compliance Agreement, the 1995 UN Fish Stocks Agreement and sustainable fisheries; ${ }^{4}$ the legal underpinnings of the precautionary principle and sustainable development; convergence and divergence in the regulatory frameworks applicable to climate change and the ocean; as well as more recently about treaty-making efforts at the United Nations to address scientific concerns regarding the threats posed by human activities to the conservation and sustainable use of high seas biodiversity. ${ }^{55}$ The latter is the oldest and less understood biome on the planet and thus remains a creative frontier in both a scientific and legal sense in its own right. Thus, it is entirely fitting that in Chapter 15 Philomène Verlaan addresses the question of the creative environment of the frontier directly in her contribution to the volume. ${ }^{56}$ The author considers the marine environment to be a frontier, whose 'precise boundaries can never be firmly fixed because of the myriad spatial, temporal, physical, geochemical and biological characteristics that require connection, not separation, for the marine environment to flourish. ${ }^{57}$ The central thrust of the arguments advanced by Verlaan is premised upon the poor record of humans in managing anthropogenic impacts on the environment and the consequent need to challenge the limited and boundary-driven approach by taking the nature and needs of the ocean as a starting point for future decision-making and stewardship. In this context, she highlights the need to set up a new creative space within which both boundaries and frontiers must be questioned, especially in terms of their potential to serve as barriers to effective management and in striving for long term solutions. In the absence of a creative approach, the author flags the risks associated with the incorporation of limited concepts into legally binding instruments, taking as an example the discrete and preferential treatment afforded to biological diversity beyond national jurisdiction under the putative new в вNJ Agreement under the LOSC. ${ }^{58}$ Her arguments are

53 D Freestone, 'Responsibilities and Obligations of States Sponsoring Persons and Entities with Respect to Activities in the Area' (2011) 5(4) American Journal of International Law 755-76o.

54 See W Edeson, D Freestone, and E Gudmundsdottir, Legislating for Sustainable Fisheries: A Guide to Implementing the 1993 FAO Compliance Agreement and the 1995 Fish Stocks Agreement (World Bank, 2001).

55 D Freestone (ed.), Conserving Biodiversity in Areas beyond National Jurisdiction (Brill/ Nijhoff, 2019).

56 Chapter 15: "The Interface of Science and Law: A Challenge to the Privileging of "Marine Biodiversity" over "Marine Environment".

57 Ibid 410.

$5^{8}$ United Nations General Assembly, Draft text of an agreement under the United Nations Convention on the Law of the Sea on the conservation and sustainable use of marine 
compelling from both scientific and legal perspectives and shine the spotlight on the inadequacies of the LOSC and the BвNJ Agreement in safeguarding the structure and functioning of ecosystems within ecologically meaningful boundaries as a whole. Crucially, the establishment and honing of a creative space for this purpose will sit well with the obligations set forth in the LOSC to protect and preserve the marine environment and the pressing imperatives of furthering international cooperation to maintain and improve the environment. Furthermore, it accords fully with David Freestone's avant-garde work on the Principles of Modern Ocean Governance including most notably the application of normative and scientific tools in a range of multilateral and regional instruments, ${ }^{59}$ about which he articulated so succinctly at the 2008 IUCN $4^{\text {th }}$ World Conservation Congress in Barcelona on 7 October 2008. One of the outstanding features of David's métier is deftness in redressing the environmental imbalance and undue deference to navigation rights that is such a distinctive feature of the LOSC. In doing so, he has championed inclusive governance arrangements that are capable of accommodating the various interdependencies and interests that are juxtaposed in the protection of the ocean as a whole and as highly functioning and complex social-ecological systems. The need for new approaches is all the more crucial in light of the relentless emphasis on exclusive use and value positions that characterize the demands and expectations of frontier actors on frontier issues.

The interconnectedness of the marine environment and the metaphor of the frontier are particularly apt when considering the application of procedural law to minimizing adverse impacts of human activities on the ocean both within and beyond national jurisdiction. The obligation under the LOSC to undertake analysis and assessment of planned activities are clear and provide a useful benchmark for measuring the effectiveness of regulatory regimes in mitigating environmental damage. ${ }^{60}$ Moreover, in the intervening period since the coming into force of the LOSC, the demarcation lines of State authority and the responsibilities of public and private actors are less blurred with the International Court of Justice holding in the Pulp Mills on the River Uruguay case that environmental impact assessment (EIA) is 'a requirement under general international law', ${ }^{61}$ as well as affirming the critical links that co-exist

biological diversity of areas beyond national jurisdiction (BвNJ Agreement), UN Doc A/ CONF.232/2019/6 (17 May 2019).

59 D Freestone, 'Principles Applicable to Modern Oceans Governance' (2008) 23 International Journal of Marine and Coastal Law 385-391.

6o Losc, above (n 29), Arts 205-206.

61 Pulp Mills on the River Uruguay (Argentina v Uruguay), Judgment, (2010) ICJ Reports, p 14, para 204. 
between procedural obligations and substantive obligations pertaining to prevent pollution and preserve the aquatic environment. ${ }^{62}$ In instances of transboundary harm, it is significant that Judges Al-Khasawneh and Simma in their joint separate opinion highlighted the extreme elasticity and generality of the substantive principles that are at play and in their view procedural obligations are an essential indicator of whether substantive obligations were or were not breached. ${ }^{63}$ Again the significance of Freestone's scholarship is evident and it plays a catalytic role in exploring the boundaries for the application of preventive and anticipatory means including precautionary measures, EIA, new clean technologies and the best available science with a view to preventing, reducing and restoring the degradation of the marine environment.

In this light, the concept of the frontier provides an innovative framework in understanding the treaty-making efforts that are underway in developing an overarching strategic environmental assessment (SEA) during the course of the вв NJ negotiations as described by Robin Warner in Chapter 16, which focuses on the concept of strategic environmental assessment (SEA) and the potential elements in an SEA process, along with the relationship between EIA and SEA and the relevance of SEA to marine spatial planning. ${ }^{64}$ From this discussion, it is evident that the benefits of SEA provisions in the BBNJ Agreement are tangible and will be aimed at mitigating the adverse impact of plans, policies and programmes where a range of human activities occur over longer time frames. Warner notes, however, that the challenges are considerable due to the oceanic scale, the chasm in scientific knowledge of the existence, functioning and status of deep-sea biodiversity, the absence of appropriate governance structures, as well as resources and technical capacity to undertake appropriate strategic assessment. In light of these considerations, she writes presciently that SEA may only evolve over the longer term as knowledge of deep-sea biodiversity increases and with the establishment of the necessary resources and governance structures. This requires recognizing how future normative obligations will have to evolve through regulatory, institutional, executive or adjudicative processes to meet the challenges in sustainable development or environmental protection. Furthermore, the normative strength and influence of the SEA provisions, along with the interests of the multiple stakeholders involved in conserving and sustainably using marine biodiversity in $\mathrm{ABNJ}$, will perhaps crystallise over time. The provisions should not therefore be viewed solely

62 Ibid para $190-7$.

63 Ibid, separate reasons of Judges Al-Khasawneh and Simma, para 26.

64 Chapter 16: 'Strategic Environmental Assessment and Its Application to Marine Areas beyond National Jurisdiction'. 
in technical terms but as a crucible that fosters iterative processes including enhanced stakeholder engagement in the frontier space where science and law are unable to provide definitive and easily digestible answers. ${ }^{65}$

The continuous changes revealed by science in the ocean environment due to natural and anthropogenic impacts can be contrasted with the relatively slow and pedantic nature of international law-making and implementation. In this task, the LOSC is primarily concerned with the allocation of resources and other entitlements in relation to the use of maritime space. The flexibility of the LOSC in responding to new environmental circumstances is derived mainly on the other hand from several carefully crafted provisions including the 'rules of reference' provisions that draw upon generally accepted international rules or standards, the malleable standard of due diligence as enunciated by international courts and tribunals, along with the fundamental obligation placed on States to cooperate in advancing the protection of the ocean as a whole. Regional treaties and the role of regional organizations are also of paramount importance in strengthening the global framework and in establishing new marine environmental management and stewardship arrangements. Again, in this context, one of the distinctive features of David's career is the manner in which it has bridged the academic and realpolitik of international leadership in regime building. Nowhere is this more evident than in his work in relation to Sargasso Sea as mapped out in Chapter 17 by Kristina Gjerde and Ole Varmer, who recount the extraordinary role he has played in the genesis and development of the Sargasso Sea Commission (ssc) ${ }^{66}$ In doing so, he has used his considerable acumen in developing the SSC as an innovative regional governance arrangement that provides for stewardship, precaution and sciencebased management in one of the world's great hotspots of marine biodiversity. The creative space of the frontier is to the fore with the policy and regulatory narratives under David's leadership developing from the informal Sargasso Sea Alliance evolved into a sophisticated tripartite entity: the Sargasso Sea Commission (SSC) operating as a stand-alone legal entity established under Bermudian and US law. A number of key features of the SSC are described by the authors and extend to institutional structures and processes that are necessary to secure the full components of effective governance, including longterm accountability, transparency, responsiveness, rule of law, stability, equity and inclusiveness, and empowerment, as well as broad-based engagement and participation of stakeholders. The chapter concludes with the observation that

65 N Craic, "The Duty to Cooperate in the Customary Law of Environmental Impact Assessment' (2020) 69(1) International and Comparative Law Quarterly 239-259. 
public-private partnerships such as those spearheaded by David Freestone can play an essential role in fostering stewardship in remote environmental frontiers. At the same time, the chapter provides a compelling case study that demonstrates the need for robust global rules and processes and strengthened regional capacity to advance coordinated conservation and sustainable use activities. This is all the more remarkable because it is one of a few examples worldwide where regional arrangements have evolved pari-passu with the ввNJ negotiations at the UN. One of the objectives of the chapter is to show how David Freestone's work has influenced the deliberations of the international community in bringing the BBNJ intergovernmental conference to a successful conclusion in the form of a legally binding agreement.

A similar theme runs through the contribution of Ambassador David Balton in Chapter 18, who reviews possible future approaches that advance international governance of the Sargasso Sea including tabling the notion of the development of a hybrid model, reflecting elements of both the CCAMLR and OSPAR approaches to ocean governance. Again, the author points to the creation of possible synergies between the unique development of a distinctive regional regime guided by David Freestone with the negotiation and expected entry into force of a new ввNJ Agreement. The Sargasso Sea governance arrangements thus have the potential to demonstrate how governments can, in respect of a given area beyond national jurisdiction, develop and implement areabased management tools, conduct environmental impact assessments, and improve knowledge related to marine genetic resources. Moreover, the вв NJ Agreement may rely on regional bodies to implement at least some aspects of its provisions once it enters into force. The ssc thus will remain at the cusp of frontier developments in relation to governance, institutions and the dynamic inter-play between ocean science and as a basis for systemic regime cooperation and coordination. Both chapter 17 and 18 demonstrate that the frontiers for regional governance are open to adaptation and progressive development that responds to new scientific evidence concerning the status of the marine environment. Ultimately, the experience of the Sargasso Sea shows how strong leadership and the application of scientific and legal knowledge can forge pathways into new frontiers and overcoming daunting challenges concerning the protection and preservation of marine ecosystems and biodiversity.

\subsection{New Frontiers}

The foregoing sections explored the idea of a frontier in terms of actors, spaces, process, and in terms of the interface between legal regimes or between law and other disciplines. It is evident that considerable efforts are being devoted to meeting the challenges of oceans governance, that we are pushing forward 
frontiers. If successful, then we are entering a phase in which the ocean as a frontier space could be coming to an end. Gaps in international fisheries regimes are being filled, and integrated management regimes and institutions are emerging, such as through the ввNJ Agreement negotiations. The oceans are limited physically and so too the oceans' frontiers, so it seems only logical that the frontiers will eventually disappear. Law is expanding to address gaps at an unprecedented rate and helping 'tame' ocean frontiers. The oceans could be enclosed within either coastal State waters or collectively managed areas beyond national jurisdiction. Boundaries will remain, and so too grey areas where the delimitation of maritime areas have not been resolved between claimant States. This enclosure of the oceans may pose its own challenges. For example, does the absence of a liminal space mean that tensions are heightened as actors and activities are brought closer together? Are frontiers required to maintain buffer zones? As shown by the chapters in this collection, frontiers also provide a creative crucible, one that could be lost and so hamper the dynamic development of law.

However, the frontier is not merely a legal space waiting to be filled; it is also a conceptual space. The physical frontier may be diminished, but this does not end frontier thinking. Also, we are increasingly aware of the limits in our understanding of the natural and social world, so frontiers in knowledge will continue to be a feature of how we perceive and relate to the oceans and the wider natural world. Arguably, the conceptual and knowledge frontiers offer up much greater challenges for the future. A wider body of literature is engaged with understanding law in the age of the Anthropocene - an era in which we can perceive, understand and begin to act to address the profound impact that humans have on the natural world.

In Chapter 19, Ellen Hey returns to the core notion of a frontier and uses this to explore discourse on the Anthropocene. ${ }^{67}$ She seeks to draw out some of the ideas and issues in the foregoing chapters and explores what is at stake for the future of international law of the sea and environmental law going forward. She begins by observing that there is a relationship between the frontier and centre, so that what happens in one affects the other. This echoes the points made in Part 3, that new frontier challenges force us to re-evaluate how existing institutions work, be it to address sea level rise or plastic pollution. This holds true for the development of conceptual frontiers. If we develop a new conceptual frontier, such as the Anthropocene, it requires us to rethink existing conceptual approaches. The rethinking concerns the relationship between

67 Chapter 19: 'The Anthropocene, Five Discourses and Frontier Space'. 
the natural world and what it means to be human in this world: 'As a result, the idea that the natural sciences deal with nature and relationships in nature and the social sciences and humanities with society and relationships in society becomes contested' 68

Hey suggests five Anthropocene discourses that can help us navigate the new conceptual frontier (i.e., 'Stratigraphic', 'Earth System Science', 'Earth System Governance', 'Critical' and 'Legal Discourses'). These discourses are connected, but still developing. For example, Earth System Governance considers how governance architecture can be developed in response to the idea of the Earth as a single, complex and dynamic system and subsystems. ${ }^{69} \mathrm{In}$ particular, it is concerned with governance beyond the State - something that captures the efforts to establish a governance regime for the Sargasso Sea. ${ }^{70}$ These approaches have important implications for how we undertake scholarship as we move to rethink how we combine insights from different disciplines and develop methodologies that can handle multiple disciplinary insights in a coherent manner. Sometimes this challenge can be readily embraced. For example, critical discourse may provide insights into the assumptions about how we design Earth system governance. On the other hand, Earth system science scholarship remains largely isolated from wider social science insights from other Anthropocene discourse. Here we need to be creative and pluralistic. Hey suggests that future interactions will depend upon knowledge integration and participatory research. She also argues that we need to challenge the distinction between nature/society and objective/subjective knowledge that sometimes follows because it is increasingly clear that 'natural facts', for example, the advent of the Anthropocene in geological terms, are loaded with normative implications. That we are presented with the 'fact' of an era where human activities profoundly influence global systems demands that we adjust our behaviours. As active participants (frontier actors) in such debates, we must reflect on how we shape this conceptual frontier.

David Freestone has been challenging and advancing the frontiers of the law of the sea and related disciplines his entire career. This work was recognized in

68 Ibid 518.

69 F Biermann, "'Earth System Governance” as a Crosscutting Theme of Global Change Research' (2007) 17 Global Environmental Change 326-337. See further Chapters 13 and 14 in this volume. 
2007 when he was awarded the Elizabeth Haub Prize for exceptional achievements in the field of environmental law. This is the most prestigious award that can be conferred upon an environmental lawyer. Sometimes he has observed the frontier nature of this endeavour directly: 'It has been suggested that the elements of lawlessness are reminiscent of the $19^{\text {th }}$ century frontier areas of the "wild west" in the USA; governance of ABNJ is also perhaps the last, the final, major issue still to remain unresolved under the regime of the 1982 Law of the Sea Convention.71 But most times, he has been immersed in the challenge of pushing intellectual and practical frontiers often through his work. Even if we use simple measures of quantity, then the contribution David has made is notable, but it is a combination of the innovation, insight and intellectual determination that marks his work as ground-breaking. It is impossible to do this work justice in a short introductory chapter. David has authored or edited 31 books or major reports; 186 articles/book chapters; and another 19 reports. At least five papers are pending publication, so we should acknowledge that this is work in progress.

Whilst David is internationally noted for his contributions to law of the sea and international environmental law, his first forays into publishing focused on the law of the European Economic Community (EC). This was very much a burgeoning area of law, especially given that the United Kingdom had acceded to the Treaty of Rome and junior lecturers, then as now, are still expected to keep a hand of the core professional qualifying degree subjects. David examined variously the reception of Community law into English law, ${ }^{72}$ terrorism, ${ }^{73}$ sex discrimination and, more widely, the EC's legal and political structures. ${ }^{74}$ Indeed a remarkable feature of the calibre of his early work on EC law is that a significant proportion of it was published in the Modern Law Review, which is ranked as the most prestigious law journal in the United Kingdom. Needless to say, David also turned his attention to the Common Fisheries Policy and to cutting-edge scholarship on European competence in relation to EEzs of the

71 D Freestone, 'The Final Frontier: The Law of the Sea Convention and Areas beyond National Jurisdiction' in HN Scheiber, MS Kwon and EA Gardner (eds), Securing the Oceans for the Next Generation (LOSI Conference Papers, 2012).

72 D Freestone, 'Unenforceable Community Rights?' (1978) 41(3) Modern Law Review $346-35^{2}$.

73 D Freestone, 'The EEC Treaty and Common Action on Terrorism' (1984) 4 Yearbook of European Law 207-230.

74 D Freestone and JS Davidson, The Institutional Framework of the European Communities (Croom Helm, 1988). 
member States, ${ }^{75}$ something that continues to occupy the minds of lawyers, diplomats and politicians today. However, it is perhaps a mark of his adaptive approach, and focus on the bigger picture, that he soon turned his attention to more daunting global challenges.

A significant development in David's career, and in the law of the sea, was the founding of the International Journal of Estuarine and Coastal Law in 1985. Now known as the International Journal of Marine and Coastal Law, it is in its

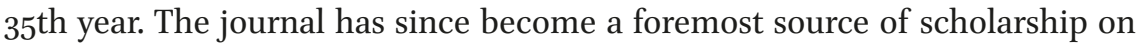
the law of the sea. Individual scholarship is important, but so too is developing a scholarly community, and taking time to nurture new ideas. Like special issues of journals, edited collections play an important role in developing related ideas and allowing scholars the opportunity to work collectively. This is something that David has championed. He has been series editor of International Environment Law and Policy (with Dan Bodansky) and Legal Aspects of Sustainable Development for over 20 years. David has edited a number of important collections. The North Sea: Perspectives on Regional Environmental Co-operation was one the earliest collections of research showing the significance of regional environmental protection regimes. ${ }^{76}$ Both International Law and Global Climate Change, edited with Robin Churchill, and The Precautionary Principle and International Law: The Challenge of Implementation, edited with Ellen Hey, broke new ground in their respective fields. ${ }^{77}$ International Law and Sustainable Development: Past Achievements and Future Challenges, ${ }^{78}$ edited with Alan Boyle, is also a tribute to the work of Pat Birnie, and so a contribution to the community of scholarship in a personal, as well as intellectual sense. ${ }^{79}$ The Law of the Sea: Progress and Prospects marked

75 D Freestone and A Fleisch, 'The Common Fisheries Policy' in L Lodge (ed.), Institutions and Policies of the European Communities (Francis Pinter, 1983) 77-84; D Freestone, 'Some Institutional Implications of the Establishment of Exclusive Economic Zones by EC Member States' (1992) 23 Ocean Development and International Law 97-114.

76 D Freestone and T Ijlstra (eds), The North Sea: Perspectives on Regional Environmental Cooperation (Graham and Trotman/Martinus Nijhoff, 199o).

77 RR Churchill and D Freestone (eds), International Law and Global Climate Change (Graham and Trotman/ Martinus Nijhoff, 1991); D Freestone and E Hey (eds), The Precautionary Principle and International Law: The Challenge of Implementation (Kluwer Law International, 1996).

78 AE Boyle and D Freestone (eds), International Law and Sustainable Development: Past Achievements and Future Challenges (Oxford University Press, 1999).

79 Similar papers recognizing landmark contributions of scholars include: D Freestone, 'The Establishment, Role and Evolution of the Global Environment Facility: Opera tionalising Common but Differentiated Responsibility?' in TM Ndiaye and R Wolfrum (eds), Liber Amicorum for Thomas A. Mensah: Law of the Sea, Protection of the Marine Environment and Settlement of Disputes (Martinus Nijhoff, 2007); 'A Decade of the Law of 
the tenth anniversary of the entry into force of the LOSC, and took stock of its contributions to governance of the oceans. ${ }^{80}$ Recognizing the growing challenge of climate change, the collection Legal Aspects of Carbon Trading: Kyoto, Copenhagen and Beyond (with Charlotte Streck), broke new ground by investigating in detail how climate commitments could be implemented, combining an analysis of public and private approaches to regulation. ${ }^{81}$

Another important task has been his curation of existing scholarship. David's collection, Sustainable Development and International Environmental $L a w,{ }^{82}$ is a timely reminder of the progress we have made since the 1972 Stockholm UN Conference on the Human Environment. More recently, he published Conserving Biodiversity in Areas beyond National Jurisdiction, ${ }^{83}$ which brings together leading contributions concerning the quite critical question of how best to govern areas beyond national jurisdiction. In fields with extensive scholarship, being able to navigate and showcase the most significant scholarly contributions provides an important roadmap for future research.

David's individual contributions to scholarship are wide-ranging but perhaps can be grouped into three themes: protection of vulnerable regimes; institutional and governance processes; and regime interactions.

Initially focusing on the degradation of regional marine environments, ${ }^{84}$ David has since been proactive in calling for the strengthening of global and

the Sea Convention: Is it a Success?' (2007) 39 George Washington University International Law Review 101-143 (Special Issue on the Symposium in Remembrance of Professor Louis Sohn); 'Can the UN Climate Regime Respond to the Challenges of Sea Level Rise?' in 'Report of the Symposium in Honor of Jon Van Dyke' (2013) 35(2) University of Hawai'i Law Review 671-685; 'Satya Nandan's Contribution to the Development of the Precautionary Approach in International Law' in M Lodge and M Nordquist (eds), Peaceful Order in the World's Ocean: Essays in Honor of Satya Nandan (Martinus Nijhoff, 2014) 308-324; and 'Marine Biodiversity in Areas beyond National Jurisdiction' in D Werle et al. (eds),The Future of Ocean Governance and Capacity Development: Essays in Honour of Elisabeth Mann Borgese (1918-2002) (Brill/Nijhoff, 2018) 151-156.

8o D Freestone, R Barnes and D Ong (eds), The Law of the Sea: Progress and Prospects (Oxford University Press, 2006).

81 D Freestone and C Streck (eds), Legal Aspects of Carbon Trading: Kyoto, Copenhagen and Beyond (Oxford University Press, 2009).

82 D Freestone (ed.), Sustainable Development and International Environmental Law (Edward Elgar, 2018).

83 D Freestone (ed.), Conserving Biodiversity in Areas beyond National Jurisdiction (Brill/ Nijhoff, 2019).

84 See, for example, D Freestone, 'Specially Protected Areas and Wildlife in the Caribbean: The 1990 Kingston Protocol to the Cartagena Convention' (1997) 5 International Journal of Estuarine and Coastal Law 396-416; D Freestone, 'The North Sea Declaration on the Coordinated Extension of Jurisdiction' (1993) 8 International Journal of Marine and Coastal Law $172-175$. 
inclusive governance regimes. In 'The Conservation of Marine Ecosystems under International Law', David argued for a holistic approach to the governance of biodiversity, noting that that the guiding agenda of biodiversity debates was the issue of ownership and exploitation, rather than conservation. ${ }^{85}$ In particular, David has made important contributions to understanding the importance of space in governing ocean regimes. He has argued for stronger regional seas protection, ${ }^{86}$ as well as the use of spatial tools such Particularly Sensitive Sea Areas ${ }^{87}$ and marine protected areas. ${ }^{88}$ David is perhaps best known for his contributions to the precautionary principle - arguably the principle prima inter pares of frontier governance paradigms. He has been at the forefront of debates about the precautionary principle in international law for over three decades. ${ }^{89}$ Unsurprisingly perhaps, he is a leading advocate of its use in fisheries management, a field where the principle is absolutely critical to the sustainable management of depleted resources. ${ }^{90}$ As in other areas, David has been key in bridging the gaps between academia and practice, and so has sought to assist the implementation of the principle in practice. ${ }^{91}$

85 In M Bowman and C Redgwell (eds), International Law and the Conservation of Marine Biodiversity (Kluwer Law International, 1996) 91-107.

86 Above (n 84). See also, D Freestone and N Gunningham, 'Towards Sustainable Tourism in the Wider Caribbean Region: Beyond Command and Control' in F Weiss et al., Towards International Economic Law with a Human Face (Kluwer Law International, 1998) 357-386; R Warner, K Gjerde and D Freestone, 'Regional Governance for Fisheries and Biodiversity' in SM Garcia, J Rice, and AT Charles (eds), Governance for Fisheries and Marine Conservation: Interactions and Co-evolution (Wiley-Blackwell, 2014) 211-224; D Freestone and C Schofield, 'Securing Ocean Spaces for the Future? The Initiative of the Pacific SIDS to Develop Regional Practice Concerning Baselines and Maritime Zone Limits' (2019) 33 Ocean Yearbook $5^{8-89}$.

87 D Freestone, 'Particularly Sensitive Sea Areas beyond National Jurisdiction: Time to Chart a New Course?' in M Nordquist, JN Moore and R Long, (eds) International Marine Economy: Law and Policy (Brill/Nijhoff, 2017) 322-361.

88 D Freestone, 'The Limits of Sectoral and Regional Efforts to Designate High Seas Marine Protected Areas' (2018) 112 AJIL Unbound 129-133.

89 'The Precautionary Principle' in Churchill and Freestone, above (n 77) 21-40; Freestone and Hey, above (n 77); and 'The Marine Environment' in JB Wiener, MD Rogers, JK Hammitt and PH Sand (eds), The Reality of Precaution: Comparing Risk Regulation in the US and Europe (Earthscan, 2010) 177-200.

9o See D Freestone and Z Makuch, 'The New International Environmental Law of Fisheries: The 1995 Straddling Stocks Agreement' (1996) 7 Yearbook of International Environmental Law 3-49; D Freestone, 'Caution or Precaution: "A rose by any other name ...?" ' in (1999) 10 Yearbook of International Environmental Law 25-32; and D Freestone, 'Implementing Precaution Cautiously: The Precautionary Approach in the 1995 Straddling Stocks Agreement' in Freestone and Hey, ibid 287-325.

See Edeson, Freestone and Gudmundsdottir, above ( $\mathrm{n}_{54}$ ). 
David has a longstanding interest in the role of institutions in governing environmental issues. In 1992, his article on EEZ claims by European States, explored the assumption of coordinated marine policy mandated by the EC, and flagged the concerns of a growing exclusive EC mandate across all areas of marine governance. ${ }^{92} \mathrm{~A}$ series of papers has explored how existing law of the sea institutions can adapt to new challenges. "Flexibility and Innovation in the Law of the Sea: Will the Los Convention amendment procedures ever be used?' showed the significant procedural barriers to changes in the LOSC. ${ }^{93}$ Given that there are gaps in the law of the sea, ${ }^{94}$ the issue of how existing institutions can evolve to address new challenges has since becomes a critical theme in the literature; something addressed in later papers by David and other writers. ${ }^{95}$

As some of the contributions in this collection show, institutions play a pivotal role in in mediating legal change. Through his work at the World Bank, David developed insights into how best institutions can supplement or drive developments in response to environmental and development needs. ${ }^{96}$ His 2001 essay on safeguarding policies of the World Bank was the first evaluation of the Bank's policies. ${ }^{97}$ In it he examined the development and practice of the World Bank Inspection Panel, characterizing it as an accountability

92 D Freestone, 'Some Institutional Implications of the Establishment of Exclusive Economic Zones by the Member States of the European Community' (1992) 22 Ocean Development and International Law 97-117.

93 D Freestone and AG Oude Elferink, "Flexibility and Innovation in the Law of the Sea: Will the LOS Convention amendment procedures ever be used?' in AG Oude Elferink (ed.), Stability and Change in the Law of the Sea: The Role of the LOS Convention (Martinus Nijhoff, 2005) 169-222.

94 'The Law of the Sea Convention: Unfinished Agendas and Future Challenges' (ed. with G Mangone: (1995) International Journal of Marine and Coastal Law Special Issue; 'Unfinished Business: Deep-Sea Fisheries and the Conservation of Marine Biodiversity beyond National Jurisdiction' (2004) 19 International Journal of Marine and Coastal Law. 209-223 (with K Gjerde).

95 See D Freestone, D Johnson, J Ardron, S Unger and KK Morrison, 'Can existing institutions protect biodiversity in areas beyond national jurisdiction? Experiences from two on-going processes' (2014) 42 Marine Policy 167-175; D Freestone, 'Governance of Areas beyond National Jurisdiction: An Unfinished Agenda?' in J Barrett and R Barnes (eds) Law of the Sea: UNCLOS as a Living Treaty (British Institute of International and Comparative Law, 2016) 231-266.

96 See generally, D Freestone, The World Bank and Sustainable Development_Legal Essays (Martinus Nijhoff, 2012).

97 'The Environmental and Social Safeguard Policies of the World Bank and the Evolving Role of the Inspection Panel' in K Ishibashi, A Kiss and D Shelton (eds), Economic Globalization and Compliance with International Environmental Agreements (Kluwer Law International, 2003) 139-156. 
mechanism (a hybrid of elements of dispute settlement, quality assessment and internal compliance) for benchmarking environmental and social performance. This contrasts with other, more formal judicial or administrative review bodies. David argued that this new approach was necessary to internalise social and environmental values in the decision-making process. The same year, he published a paper on the World Bank's Prototype Carbon Fund, examining its innovative provisions that engaged both public and private participants in climate change responses, observing that this mechanism offered the Parties to the United Nations Framework Convention on Climate Change (UNFCCC) the opportunity to 'learn by doing. ${ }^{9}$

This body of research underpins David's creative thinking about the ways in which the regime for the Sargasso Sea could be developed, combining a strong focus on positive environmental outcomes and interdisciplinary research with insights into how institutions function. Underlying his contributions to the actual governance of the Sargasso Sea are a series of papers that showcase how regimes can develop and the lessons that can be applied to the regulation of vulnerable marine ecosystems that cut across the high seas and areas within national jurisdiction. These papers include 'The Sargasso Sea Alliance: Seeking to Protect the Sargasso Sea', ${ }^{9}$ 'The Signing of the Hamilton Declaration on Collaboration for the Conservation of the Sargasso Sea: A new paradigm for high seas conservation?', 100 'The Sargasso Sea Alliance: Working to Protect the 'Golden Floating Rain Forest of the Ocean', 101 'The Sargasso Sea Commission: An innovative approach to the conservation of areas beyond national jurisdiction,',102 and the 'Sargasso Sea.' ${ }^{103}$

Understanding how different fields of law and their institutions interact will be one of the key challenges for scholars seeking to advance better governance regimes for the oceans and for the wider environment. As indicated by Bodansky, the relationship between climate law and law of the sea

98 'The World Bank's Prototype Carbon Fund: Mobilising new Resources for Sustainable Development' in S Schemmer-Schulte and K-YTung (eds), Liber Amicorum for Ibrahim S.I. Shihata (Kluwer Law International, 2001) 265-341. (2012) 27 International Journal of Marine and Coastal Law 647-655 (with K Killerain Morrison).

100 (2014) 29 International Journal of Marine and Coastal Law 345-36 (with K Killerain Morrison).

101 (2014) 44 Environmental Policy and Law 151-158.

102 (2016) 30 Ocean Yearbook 80-90 (with Faith Bulger).

103 Chapter $7 \mathrm{~S}$ in The Second Integrated World Ocean Assessment (First World Ocean Assessment) 2021 (United Nations, New York, forthcoming) (with H Roe, B Luckhurst, L Kell and T Trott). 
is not always well understood. ${ }^{104}$ They are separate regimes with different regulatory approaches and capacity. David has sought to map out and clarify the relationship between the regimes in a series of papers. ${ }^{105} \mathrm{He}$ accepts the division of labour between the two regimes, and has in the past highlighted the tension between them. For example, he noted that duties to mitigate the effects of climate change cannot require States to engage in iron fertilization until such as time that independent, peer reviewed evidence shows the benefits outweigh the risks to the marine environment. ${ }^{106}$ Yet he also notes there are some points of intersection where synergies can be exploited, such as by coordinated measures to reduce greenhouse gas emissions from shipping, the extension of financing mechanisms under the UNFCC to oceans projects, and the development of climate-related concerns in the criteria for marine protected areas on the high seas. Going forward, this work at the frontier between the regimes will be important in coordinating and maximizing efforts to mitigate and adapt to climate change. ${ }^{107}$ The relationship between climate regimes and law of the sea is explored in a series of papers on sea level rise that can be traced back to the early 199os, and, most notably, 'International Law and Sea Level Rise.'108 This is one of the earliest surveys of the international legal issues arising from rising sea levels, and it remains a reference point in the field. David has charted developments since then, stressing the importance of stable boundaries, ${ }^{109}$ and the wider institutional support for affected

104 Bodansky, this volume.

105 See 'The United Nations Framework Convention on Climate Change-The Basis for the Climate Change Regime' in C Carlarne, K Gray and R Tarasoksky (eds), Oxford Handbook on International Climate Change Law (Oxford University Press, 2016) 101-123; "The Role of the International Climate Change Regime in Global Ocean Governance' in D Attard, D Ong and D Kritsiotis (eds), The IMLI Treatise on Global Ocean Governance. Volume i: UN and Global Ocean Governance (Oxford University Press, 2018) 149-64.

106 'D Freestone and R Rayfuse, 'Ocean Iron Fertilization and International Law' (2008) 364 Marine Ecology Progress Series 227-233.

107 'Climate change, the Anthropocene and ocean law: mapping the issues' in R Barnes, $\mathrm{J}$ McDonald and J McGee, (eds) Research Handbook on Climate Change, Oceans and Coasts (Edward Elgar, 2020).

108 Published in Churchill and Freestone, above (n 6) 109-125. See also, 'Preparing for the Rising Tides' (1990) 14 Marine Policy 456-457.

109 D Freestone and JS Pethcik, 'Sea Level Rise and Maritime Boundaries: International Implications of Impacts and Responses' in G Blake (ed.), International Boundaries; Fresh Perspectives (Routledge, 1994) 73-9o; D Freestone and C Schofield, 'Options to Protect Coastlines and Secure Maritime Jurisdictional Claims in the Face of Global Sea Level Rise' in M Gerard and G Warnier (eds), Threatened Island Nations (Cambridge University Press, 2013) 141-165; D Vidas, D Freestone and J McAdam (eds), International Law and Sea Level Rise: Report of the International Law Association Committee on International Law and Sea Level Rise, Brill Research Perspectives in the Law of the Sea (Brill Nijhoff, 2019). 
States. ${ }^{110} \mathrm{He}$ has been key in consolidating research, as well as shaping the options for response to this challenge through his contributions to the work of the International Law Association. ${ }^{111}$

Frontier scholarship must always cast an eye to the future. In keeping with this outlook, David has stressed the importance of having clear and inspirational vision. In World Heritage in the High Seas: An Idea Whose Time Has Come, he and his co-authors rightly highlighted the importance of a clear, uncompromising and inclusive visions for world heritage. ${ }^{12}$ In other works, David has sought to advance similarly clear, inclusive and uncompromising agendas, such as in a series of papers foregrounding the core principles of modern oceans governance. ${ }^{113}$ It is worth restating these here: conditional freedom of the high seas; protection and preservation of the marine environment; international cooperation; science-based approach to management; the precautionary approach; ecosystem approach; sustainable and equitable use; public availability of information; transparent and open decision-making processes; and the responsibility of states as the stewards of the marine environment. Similarly, lessons from his influential work on the Sargasso Sea, which focuses on partnership building and governance within existing institutional constraints, offer important insights for emerging regimes for the governance of areas beyond national jurisdiction. The 'unfinished agenda' that is areas beyond national jurisdiction is perhaps the most significant oceans frontier issue of our time. ${ }^{114}$ David is a pre-eminent and highly distinguished member of the ocean law and climate law communities. His reputation of professionalism and discerning intellect is a source of inspiration to his many

110 Freestone, 'Can the UN Climate Regime respond to the Challenges of Sea Level Rise?', above (n 79).

111 Second Report of the ILA Committee on Sea Level Rise and International Law (Seventyeighth ILA Conference, Sydney, 2018, with D Vidas and J McAdam); First Interim Report of the ILA Committee on Sea Level Rise and International Law (Seventy-Seventh ILA Conference, Johannesburg, 2016, with D Vidas and J McAdam).

112 D Freestone, D Laffoley, F Douvere, and T Badman, World Heritage in the High Seas: An Idea Whose Time Has Come. Applying Outstanding Universal Value beyond National Jurisdiction (Unesco World Heritage Reports No 44, July 2016).

113 Freestone, above ( $\mathrm{n}$ 59). See also, D Freestone, 'Editorial: Principles Applicable to Modern Oceans Governance' (2008) 23 International Journal of Marine and Coastal Law 385-391; D Freestone, 'Modern Principles of High Seas Governance: The Legal Underpinnings' (2009) 39 International Environmental Policy and Law 44-49; D Freestone, 'Problems of High Seas Governance' in D Vidas and PJ Schei (eds), The World Ocean in Globalisation: Challenges and Responses (Martinus Nijhoff, 2011) 99-130.

114 Freestone, 'Governance of Areas beyond National Jurisdiction: An Unfinished Agenda?', above (n 95). 
friends and colleagues worldwide. His vision and industry as a scholar, creativity and pragmatism as a diplomat and international negotiator, and singlemindedness and skill as an international lawyer have made a remarkable difference on the global stage. These attributes are also captured in the very fine contributions that comprise this Festschrift to Professor David Freestone. 
Richard Barnes and Ronán Long - 9789004372887 Downloaded from Brill.come4/26/2023 03:03:22AM via free access 